\title{
Ultrastructural studies of frozen-thawed 8-cell mouse embryos
}

\author{
D. G. Whittingham and E. Anderson* \\ M.R.C. Mammalian Development Unit, Wolfson House, University College London, London, NW1 \\ $2 H E, U . K$. and *Department of Anatomy and Laboratory of Human Reproduction and Reproductive \\ Biology, Harvard Medical School, Boston, Massachusetts 02155, U.S.A.
}

\begin{abstract}
Summary. Survival of frozen 8-cell mouse embryos transferred directly upon thawing to the uteri of Day 3 pseudopregnant foster mothers was significantly lower $(26 \%)$ than the survival of unfrozen 8-cell embryos transferred immediately after collection ( $73 \%$ ). When frozen-thawed 8-cell embryos were cultured for $20-24 \mathrm{hr}$ before transfer survival was similar to that of unfrozen 8-cell embryos transferred after 20-24 hr in culture $(65 \%$ and $73 \%$, respectively). Ultrastructural examination of the frozenthawed 8-cell embryos revealed no obvious damage to protoplasmic components.
\end{abstract}

\section{Introduction}

A high proportion of mouse embryos at all preimplantation stages of development survive freezing and thawing provided that they are cooled and thawed at suitably slow rates in the presence of dimethylsulphoxide as the cryoprotective agent (Whittingham, Leibo \& Mazur, 1972; Wilmut, 1972; Whittingham, 1974a). Viability can be assessed in two ways; development of the embryo in vitro to the blastocyst stage or development to full-term fetuses and liveborn after transfer to recipient foster mothers. In the mouse studies cited the viabilities were similar, but for frozen-thawed rabbit embryos viability was high in vitro and low in vivo (Whittingham \& Adams, 1976). However, when frozen-thawed 8-cell mouse embryos were transferred directly after thawing to the uterus of a recipient on Day 3 of pseudopregnancy only $25 \%$ survived to 14 -day fetuses compared with $73 \%$ of the controls and $65 \%$ of frozen-thawed 8-cell embryos cultured for 20-24 hr to the late morula and early blastocyst stage before transfer (for details see below). Frozen-thawed mouse embryos were therefore examined ultrastructurally for any damage to membranes and associated structures which might account for this apparent lag in the resumption of embryonic development.

\section{Materials and Methods}

Randomly bred albino CFLP female mice (Anglia Laboratories Ltd) were induced to superovulate and 8-cell embryos (CFLP $\times$ CFLP) were obtained from successfully mated mice approximately $68 \mathrm{hr}$ after the injection of HCG (for details of procedures see Biggers, Whitten \& Whittingham, 1971). The embryos were collected in a modified Dulbecco's phosphate-buffered medium (PB1 : Whittingham \& Wales, 1971) and frozen and thawed according to procedures outlined in detail elsewhere (Whittingham et al., 1972; Whittingham, 1974b). Cryoprotection was afforded with $1.5 \mathrm{M}$-dimethylsulphoxide (DMSO) and the embryos were cooled between -5 and $-80^{\circ} \mathrm{C}$ at rates ranging from 0.25 to $0.5^{\circ} \mathrm{C} / \mathrm{min}$. At $-80^{\circ} \mathrm{C}$ the embryos were transferred to liquid nitrogen $\left(-196^{\circ} \mathrm{C}\right)$ and stored for periods of up to 10.5 months. The thawing rate varied between 4 and $6^{\circ} \mathrm{C} / \mathrm{min}$ over the range of -80 to $-5^{\circ} \mathrm{C}$. The embryos in Treatments IV and V (see below) were cooled at $0.5^{\circ} \mathrm{C} / \mathrm{min}$ to $-80^{\circ} \mathrm{C}$ before transfer to liquid nitrogen and thawed at $5 \cdot 5^{\circ} \mathrm{C} / \mathrm{min}$.

Freshly collected and frozen-thawed 8-cell embryos were transferred either immediately or after 20-24 hr of culture to the uterine horns of recipients on Day 3 of pseudopregnancy (4-6 embryos/ 
uterine horn). Day 1 is the day on which the vaginal plug was found. The recipient foster mothers were either CFLP or $F_{1}(C 57 B L \times A 2 G)$ hybrid females which had mated successfully with vasectomized males previously proven sterile. Embryos were cultured in a routine mouse embryo culture medium (Whittingham, 1971) and $98 \%$ of the freshly collected 8-cell embryos (control) developed into late morulae and early blastocysts after $20-24 \mathrm{hr}$ in vitro.

For electron microscopy, the embryos were fixed in a $3 \%$ glutaraldehyde- $-0.5 \%$ paraformaldehyde mixture contained in a $0 \cdot 1 \mathrm{M}$-phosphate buffer $(\mathrm{pH} 7 \cdot 4)$. After fixation for $40 \mathrm{~min}$ at room temperature, the embryos were washed in $0 \cdot 1 \mathrm{M}$-phosphate buffer and stored in this buffer before post-fixation in $1 \%$ osmium tetroxide solution for $1.5 \mathrm{hr}$, rapid dehydration through graded alcohols, infiltration and embedding in Epon. For each sample (see below) about 10-12 blocks were made, each containing approximately $2-3$ specimens. Thin sections were cut from each block with a Porter-Blum MT-2 ultramicrotome, stained with uranyl acetate followed by a lead stain (Sato, 1958) and examined with a Philips 300 electron microscope.

The following numbers of 8-cell embryos, in which all the blastomeres appeared morphologically normal by light microscopic observation after treatment, were subsequently prepared for electron microscopy. Treatment I: 24 embryos were collected $68 \mathrm{hr}$ after the HCG injection and fixed immediately; Treatment $1 I: 17$ out of 20 embryos were recovered and fixed after being held at $0^{\circ} \mathrm{C}$ in $\mathrm{PB1}$ medium for $30 \mathrm{~min}$; Treatment $I I I: 15$ out of 15 embryos were recovered after being held at $0^{\circ} \mathrm{C}$ in the presence of $1.5 \mathrm{M}$-DMSO (15 min in PB1 medium alone plus $15 \mathrm{~min}$ in PB1 containing 1.5 M-DMSO). The DMSO was diluted out and the embryos collected and fixed; Treatment $I V: 23$ out of 30 embryos were recovered after freezing and thawing in the presence of 1.5 M-DMSO, and fixed immediately after removing the DMSO; Treatment $V: 24$ out of 30 embryos were recovered after freezing and thawing in the presence of $1.5 \mathrm{M}-\mathrm{DMSO}$, cultured for $16 \mathrm{hr}$ after the removal of DMSO and fixed.

\section{Results}

\section{Embryo transfer}

Unfrozen control 8-cell embryos transferred without culture gave significantly higher rates of survival to 14-day fetuses (see Table 1) than frozen-thawed uncultured embryos $\left(\chi_{[1]}^{2}=37.2, P<0.001\right.$ ). When both types of embryo were cultured, the proportions of embryos surviving were similar. All the recipients receiving control embryos became pregnant, but although the pregnancy rate among recipients receiving frozen-thawed embryos was slightly reduced it was not significantly different from the controls. There was no difference in the implantation rate between the $F_{1}$ hybrid and CFLP recipients.

Table 1. A comparison between the development of frozen-thawed and untreated control 8-cell mouse embryos after transfer to the uteri of recipients on Day 3 of pseudopregnancy

\begin{tabular}{|c|c|c|c|c|c|}
\hline \multirow[b]{2}{*}{ Treatment } & \multirow[b]{2}{*}{$\begin{array}{l}\text { Length } \\
\text { of } \\
\text { culture } \\
\text { (hr) }\end{array}$} & \multirow[b]{2}{*}{$\begin{array}{c}\text { No. of } \\
\text { recipients } \\
\text { pregnant } / \text { total } \\
\text { no. of } \\
\text { recipients }\end{array}$} & \multirow[b]{2}{*}{$\begin{array}{l}\text { No. of } \\
\text { embryos } \\
\text { transferred } \\
\text { to pregnant } \\
\text { recipients }\end{array}$} & \multicolumn{2}{|c|}{ At Day 14 of pregnancy } \\
\hline & & & & $\begin{array}{l}\text { No. of } \\
\text { implantation } \\
\text { sites } \\
(\%)\end{array}$ & $\begin{array}{c}\text { No. of } \\
\text { live } \\
\text { fetuses } \\
(\%)\end{array}$ \\
\hline \multirow[t]{2}{*}{ Control (unfrozen) } & $\mathbf{0}$ & $9 / 9$ & 107 & $81(76)$ & $78(73)$ \\
\hline & 24 & $8 / 8$ & $60^{*}$ & $46(77)$ & $44(73)$ \\
\hline \multirow{2}{*}{ Frozen-thawed } & 0 & $12 / 14$ & 80 & $34(43)$ & $21(26)$ \\
\hline & 24 & $39 / 43$ & 306 & $232(76)$ & $198(65)$ \\
\hline
\end{tabular}

* Out of 61 embryos cultured. 


\section{PLATE 1}
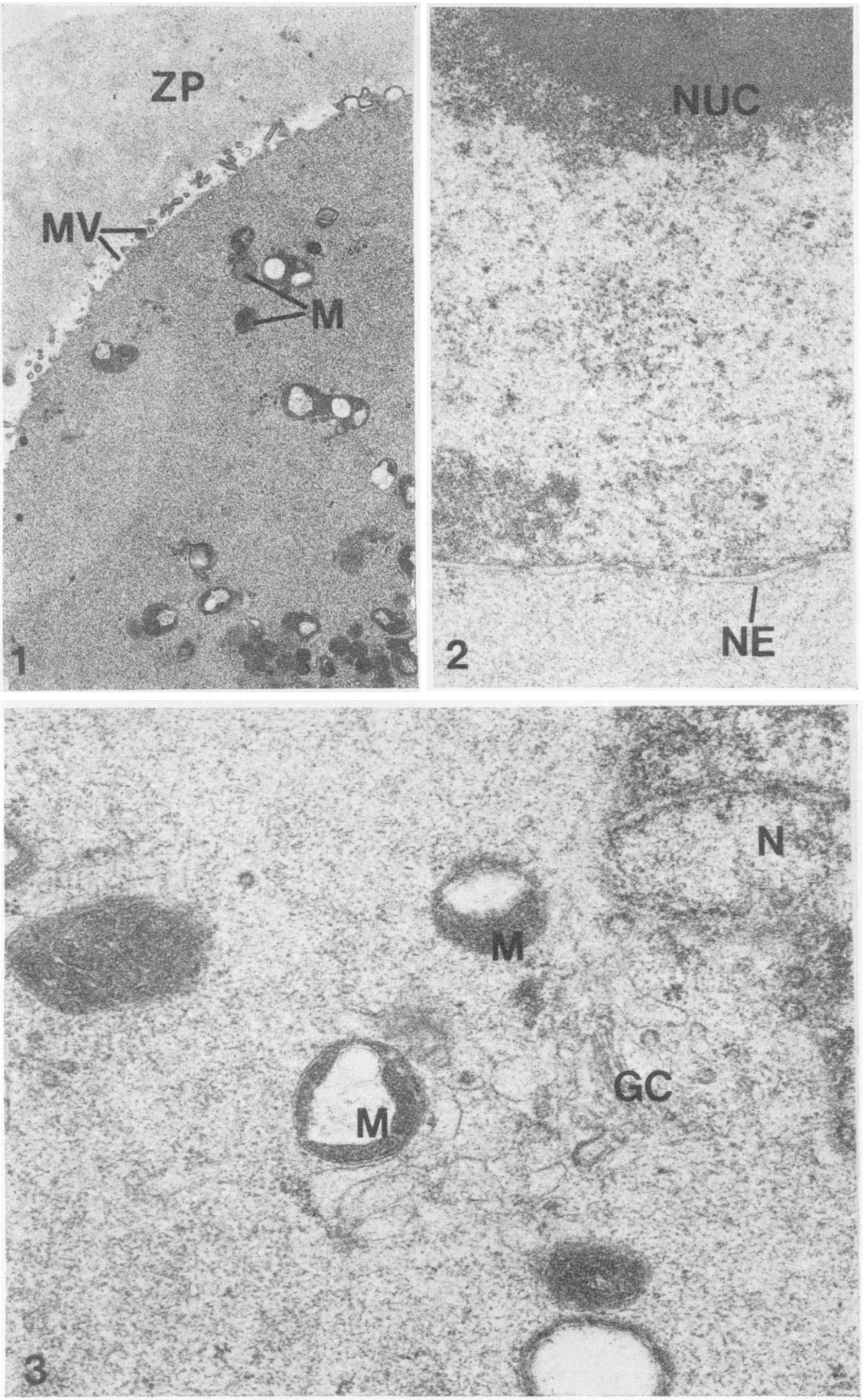

Sections through blastomeres of 8-cell mouse embryos (control, Treatment $\mathbf{I}$ ).

Fig. 1. A portion of the surface of a blastomere. ZP, zona pellucida; MV, microvilli; $M$, mitochondria. $\times 5600$.

Fig. 2. Nucleus encompassed by a double-membraned envelope (NE). NUC, nucleolus. $\times 21,600$.

Fig. 3. A small portion of the cytoplasm depicting mitochondria (M), Golgi complex, (GC) and a portion of the nucleus $(\mathrm{N}) . \times 56,000$. 
PLATE 2
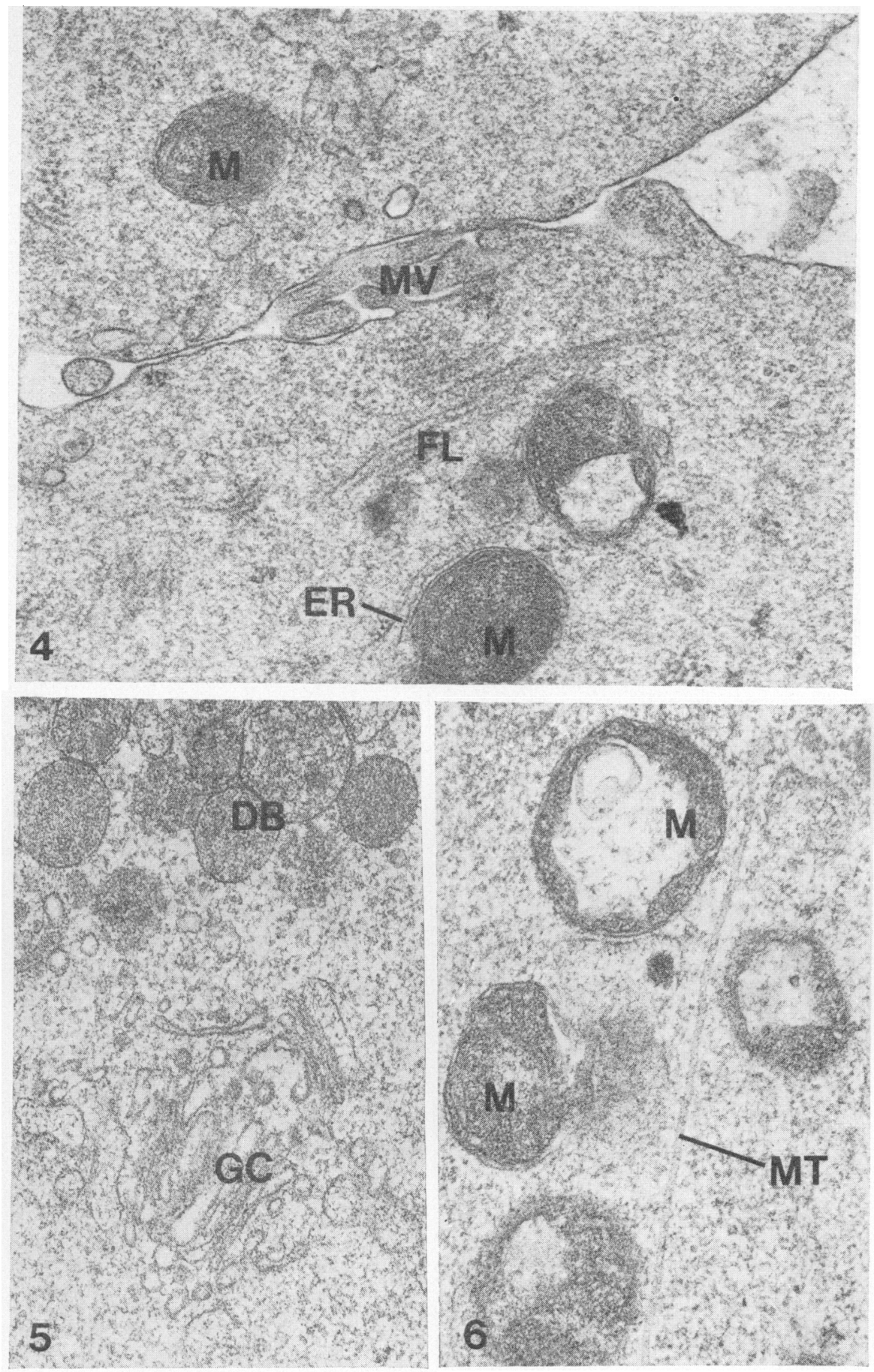

Sections through blastomeres of 8-cell mouse embryos subjected to Treatment 1 .

Fig. 4. Portions of two blastomeres. MV, microvilli; M, mitochondria; ER, endoplasmic reticulum; FI, fibrous lamellae. $\times 56,000$.

Fig. 5. Golgi complex (GC) and a cluster of dense bodies (DB). $\times 45,000$.

Fig. 6. Mitochondria (M) and a microtubule (MT). $\times 56,000$. 
PLATE 3

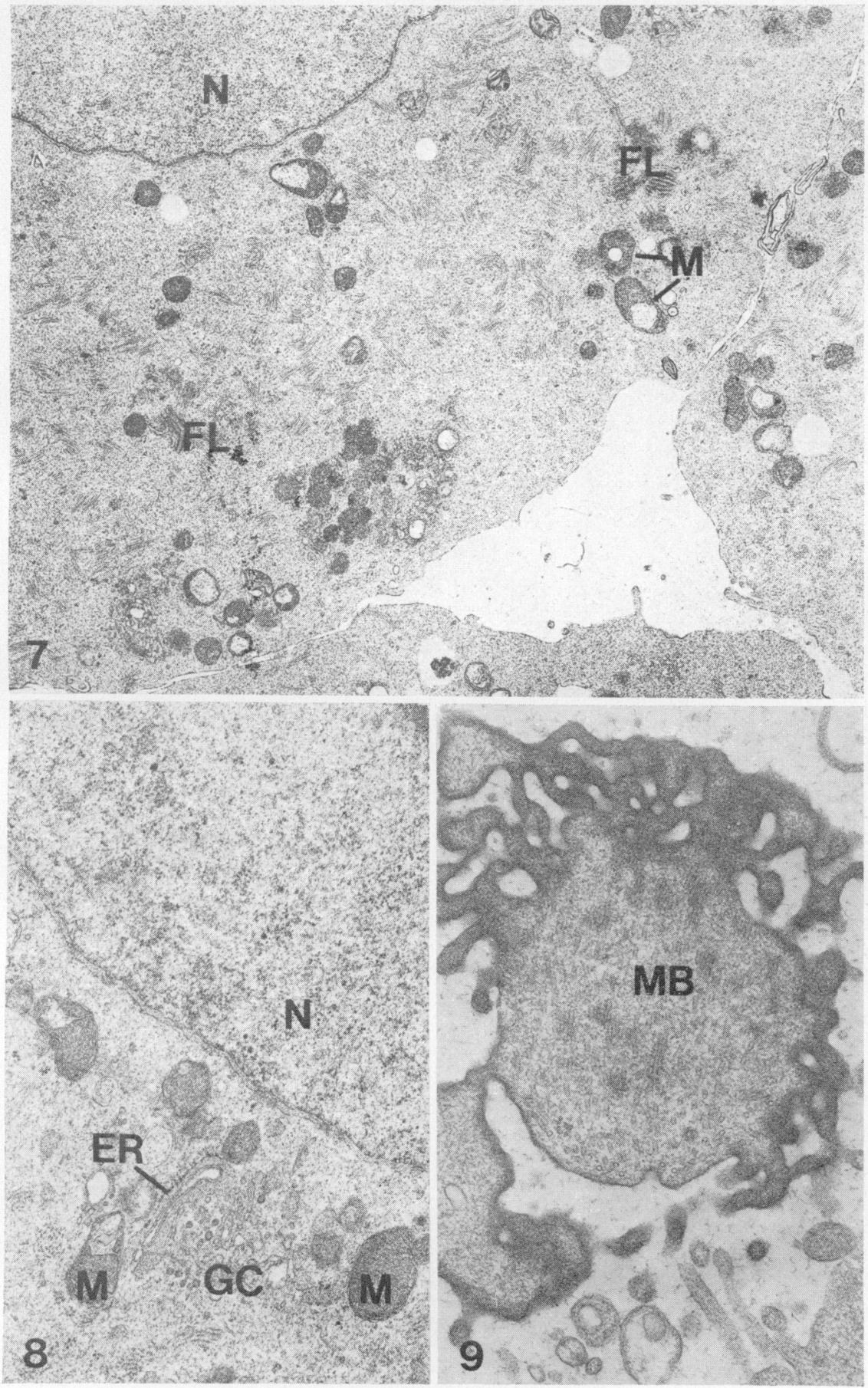

Sections through blastomeres of 8-cell mouse embryos subjected to Treatment III.

Fig. 7. A micrograph through a portion of three blastomeres. $N$, nucleus; $M$, mitochondria; FL, fibrous lamellae. $\times 5600$.

Fig. 8. Nucleus (N), endoplasmic reticulum (ER), mitochondria (M) and Golgi complex (GC). $\times 18,000$.

Fig. 9. A midbody (MB) of two blastomeres. $\times 36,000$. 


\section{PLATE 4}

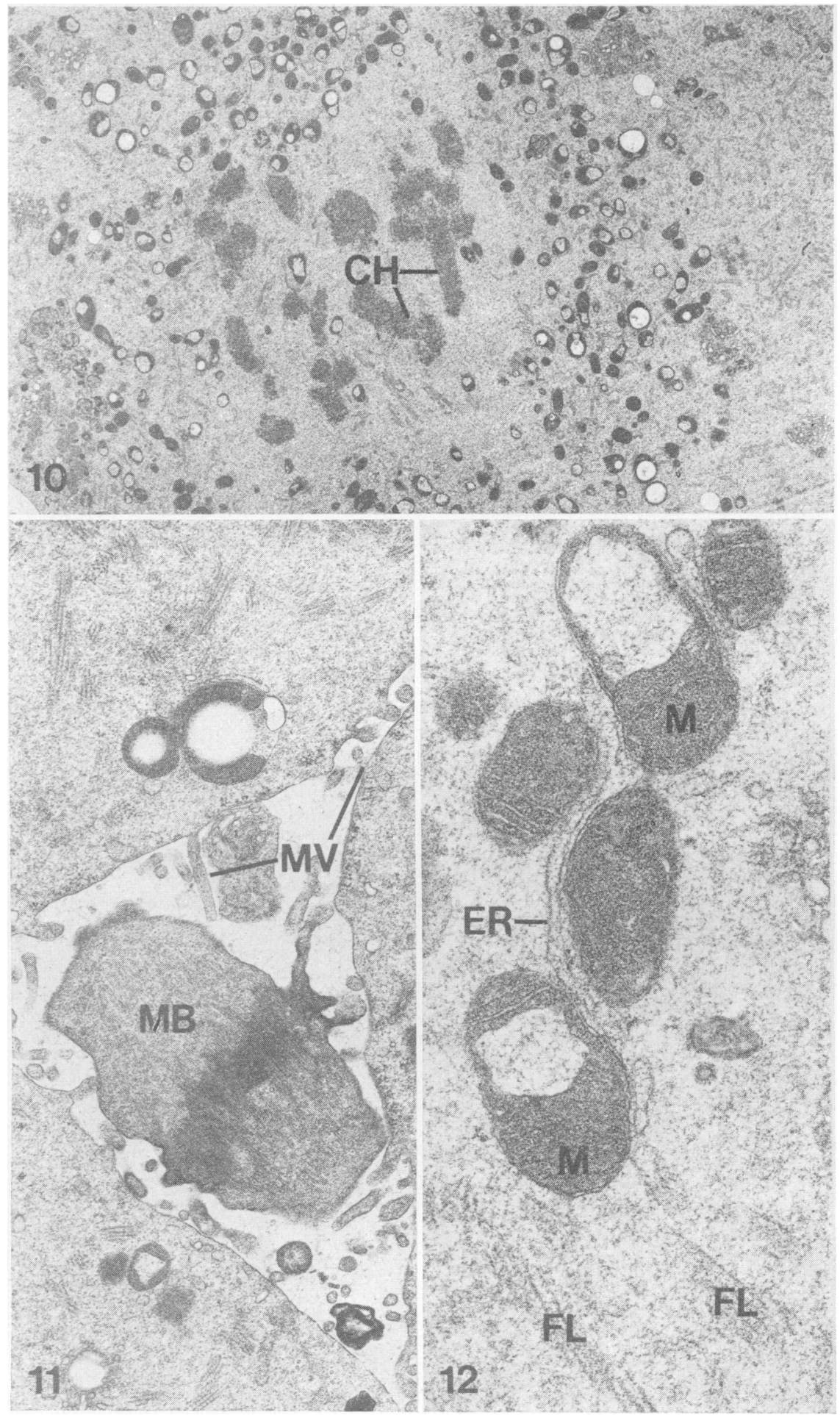

Sections through a blastomeres of 8-cell mouse embryos subjected to Treatment IV.

Fig. 10. Dividing cell. $\mathrm{CH}$, chromosome. $\times 1800$.

Fig. 11. Portions of three blastomeres (B). MB, midbody; MV, microvilli. $\times 21,600$.

Fig. 12. Mitochondria (M), endoplasmic reticulum (ER) and fibrous lamella (FL). $\times 56,000$. 
PLATE 5
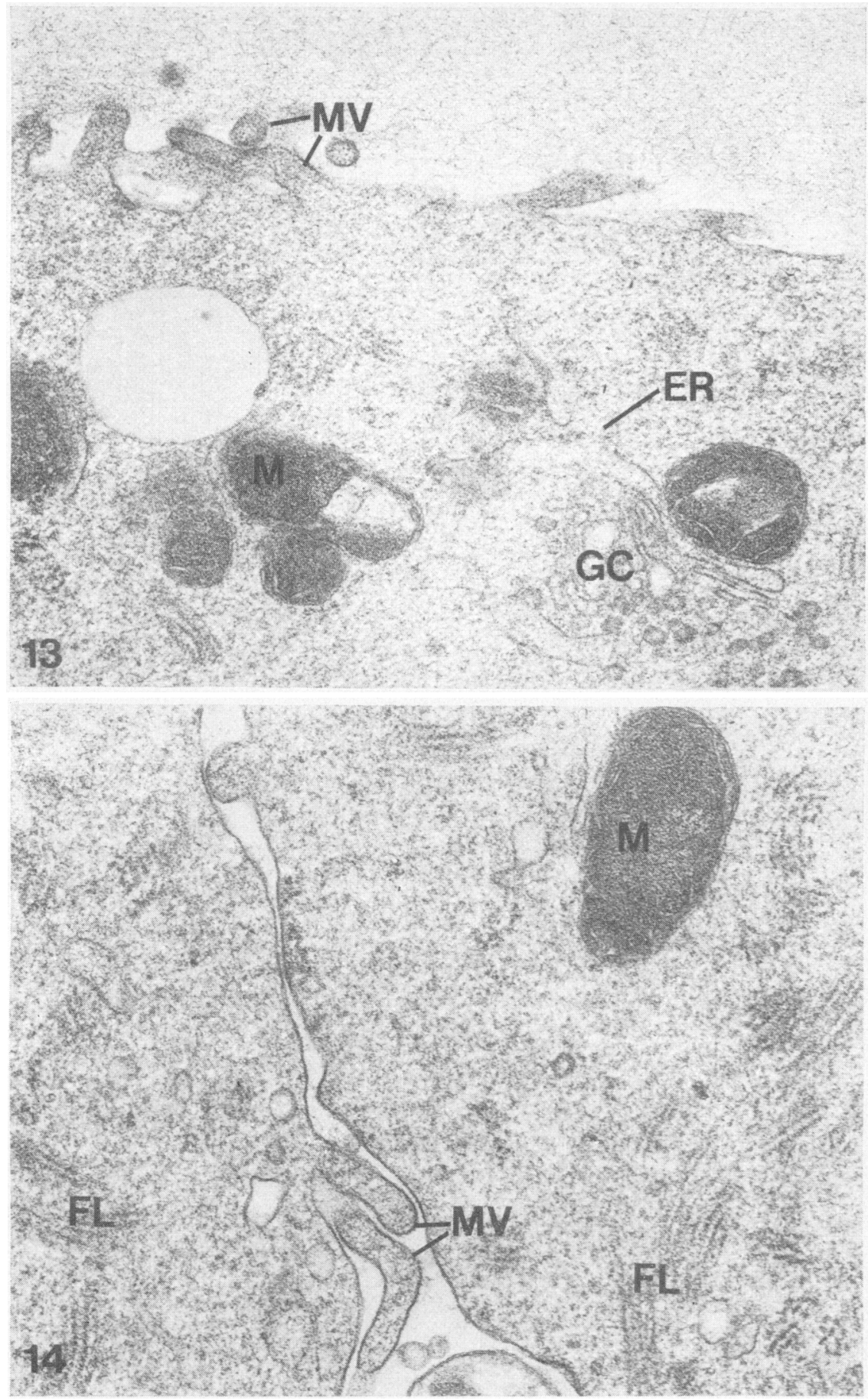

Sections through blastomeres of 8-cell mouse embryos subjected to Treatment V.

Fig. 13. A small portion of a blastomere illustrating microvilli (MV), mitochondria (M), endoplasmic reticulum (ER) and Golgi complex (GC). $\times 56,000$.

Fig. 14. A micrograph depicting two blastomeres. $M$, mitochondrion; $M V$, microvilli; FL, fibrous lamellae. $\times 56,000$. 


\section{Ultrastructure}

No observable submicroscopic disorganization of any protoplasmic components (plasma membrane, nuclear envelope, Golgi complex, mitochondria, and fibrous lamellar component) was seen in the experimental embryos (Pl. 2, Figs 4, 5 and 6; Pl. 3, Figs 7, 8 and 9; Pl. 4, Figs 10, 11 and 12; Pl. 5, Figs 13 and 14), and the organization of these embryos was equivalent to that of the controls (PI. 1, Figs 1, 2 and 3; see also Stern, Biggers \& Anderson, 1971). The blastomeres of early 8-cell experimental and control embryos were spherical, with many microvilli, and were usually closely apposed to some areas (Pl. 5, Fig. 14) (Ducibella \& Anderson, 1975). During Treatments III (Pl. 3, Fig. 9) and IV (Pl. 4, Figs 10 and 11) some blastomeres were in the process of division, but the microtubules comprising the mitotic apparatus, the midbody, and those located in the general cytoplasm (P1. 2, Fig. 5) were not depolymerized. Presumably the slow method of freezing and thawing of the embryos stabilizes the microtubules because when other cells, e.g. kangaroo fibroblasts, are chilled at $4^{\circ} \mathrm{C}$ for about $30 \mathrm{~min}$ before fixation the microtubules become depolymerized (Brinkley \& Cartwright, 1975).

\section{Discussion}

In an earlier study (Whittingham et al., 1972) the survival of frozen-thawed 8-cell embryos to 18-day fetuses and liveborn when cultured for $24-48 \mathrm{hr}$ before transfer was $55 \%(140 / 256)$. There was no significant difference in survival after culturing for 24 or $48 \mathrm{hr}$. However, the survival of frozenthawed 8-cell embryos transferred directly to the oviducts on Day 1 of pseudopregnancy was low, $38 \%(29 / 76)$. The delay observed in the present experiments should have been overcome in this type of transfer. The low survival rates for oviduct transfers were in part due to the difficulty in mastering the technique and thus make it difficult to compare results of survival by the two techniques.

The ultrastructural examination of the frozen-thawed 8-cell embryos failed to reveal any changes which may have caused this delay. There was no indication of intracellular ice damage within the blastomeres: dilatation and disorganization of mitochondria and endoplasmic reticulum and blebbing of nuclear and plasma membranes which is typically seen in cells frozen and thawed at suboptimal rates was not apparent (Bank \& Mazur, 1972; Walter, Knight \& Farrant, 1975). Nevertheless, the apparent delay in the resumption of normal development may be due to a slow and gradual restoration of normal metabolic and synthetic activity of the thawed embryo. This aspect clearly warrants further investigation as such changes at the molecular level would not necessarily be discernible by ultramicroscopical examination.

One of us (E.A.) was supported by grants (HD-06822 and Center Grant HD-06645) from the National Institutes of Health, United States Public Health Service.

\section{References}

BANK, H. \& MazUR, P. 1972) Relationship between ultrastructure and viability of frozen-thawed Chinese hamster tissue-culture cells. Expl Cell Res. 71, 441-454.

Biggers, J.D., Whitten, W.K. \& Whittingham, D.G. (1971) The culture of mouse embryos in vitro. In Methods in Mammalian Enbryology, pp. 86-116. Ed. J. C. Daniel, Jr. W. H. Freeman \& Co., San Francisco.

Brinkley, B.R. \& Cartwright, J., Jr (1975) Coldlabile and cold-stable microtubules in the mitotic spindle of mammalian cells. Ann N.Y. Acad. Sci. 253, 428-439.

Ducibella, T. \& Anderson, E. (1975) Cell shape and membrane changes in the eight-cell mouse embryo: prerequisites for morphogenesis of the blastocyst. Devl Biol. 47, 45-58.

SATo, I. (1958) A modified method for lead staining of thin sections. J. Electron Microsc. 17, 158-159.

Stern, S., Biggers, J.D. \& Anderson, E. (1971) Mitochondria and early development of the mouse. $J$. exp. Zool. 175, 179-192.

WALTer, C.A., KNIGHT, S.C. \& FARRANT, J. (1975) Ultrastructural appearance of freeze-substituted lymphocytes frozen by interrupting rapid cooling with a period at $-26^{\circ} \mathrm{C}$. Cryobiology 12, 103-109.

WhitTingham, D.G. (1971) Culture of mouse ova. $J$. Reprod. Fert., Suppl. 14, 7-21. 
Whittingham, D.G. (1974a) The viability of frozenthawed mouse blastocysts. J. Reprod. Fert. 37, 159162.

Whittingham, D.G. (1974b) Embryo banks in the future of developmental genetics. Genetics, Princeton 78, 395-402.

Whittingham, D.G. \& ADAMs, C.E. (1976) Low temperature preservation of rabbit embryos. J. Reprod. Fert. 47, 269-274.

Whittingham, D.G. \& Wales, R.G. (1969) Storage of two-cell mouse embryos in vitro. Aust.J.biol. Sci. 22, 1065-1068.

Whittingham, D.G., Leibo, S.P. \& Mazur, P. (1972) Survival of mouse embryos frozen to $-196^{\circ} \mathrm{C}$ and $-269^{\circ} \mathrm{C}$. Science, N.Y. 187, $411-414$.

WiLMur, I. (1972) The effect of cooling rate, warming rate, cryoprotective agent and stage of development on survival of mouse embryos during freezing and thawing. Life Sciences, 11, 1071-1079.

Received 3 March 1976 